\title{
EXPERIMENTAL VERIFICATION OF NUMERICAL CALCULATIONS WITH THE USE OF DIGITAL IMAGE CORRELATION
}

\author{
Piotr Bajurko, Przemysław Dobrzański \\ Center for Composite Technologies, Institute of Aviation \\ al. Krakowska 110/114, 02-256 Warsaw, Poland \\ piotr.bajurko@ilot.edu.pl,przemyslaw.dobrzanski@ilot.edu.pl
}

\begin{abstract}
The article presents the results of research work performed under the TEBUK project, aiming primarily to develop a reference methodology for assessing the impact of damage on the strength of structures made of carbon epoxy prepregs. The tests described in the paper were concerned with a fragment of the structure (FS) of the TEBUK project demonstrator, made of carbon epoxy composite, with an artificial circular delamination measuring $40 \mathrm{~mm}$ in diameter. Numerical and experimental test of FS have been performed under quasi-static compression load. The buckling of the skin observed in the delamination area, as well as the propagation of the latter were investigated. The numerical calculations have been performed with the use of the commercially available MSC Marc/ Mentat calculation suite based on the Finite Elements Methods. Results of the numerical calculations have been compared with experimental measurements made with the use of the Digital Image Correlation (DIC) method. The tests performed aimed to provide a preliminary verification of the numerical model. The results obtained have shown a very good correlation between the numerical and experimental results concerned with critical load levels at which stability of the layers separated by delamination is lost (buckling). The lack of convergence of the numerical model's results after exceeding the critical load values has rendered it impossible to unequivocally compare the results concerned with propagation of the delamination area.
\end{abstract}

Keywords: digital image correlation, FEM, delamination, buckling, carbon-epoxy laminate.

\section{INTRODUCTION}

The calculations have been performed under the POIG TEBUK Project entitled "Development of the technology for testing the resistance to damage of aviation and space composite load bearing structures" that is implemented at the Institute of Aviation. The primary aim of the article was to work out a reference methodology for assessing the impact of damage on the strength of structures made of 
modern composite materials. A number of tests have been performed under the project with a view to develop numerical methods enabling to forecast the propagation of delaminations. In order to verify the experimental numerical analyses, a TEBUK damage demonstrator, designed to mirror the horizontal tail place of the I-23 aircraft, has been built and tested. The internal structure of the stabilizer has been modified accordingly, to ensure that it is properly suited for testing the propagation of structure damage. All modifications introduced are described in $[1,2]$.

In order to reduce the quantity of material used to build the test piece, and in order to minimize labor- and time-intensity of the process of building and examining the test piece, attempts have been undertaken to identify that fragment of the demonstrator's structure (FS) that could be used to test the delamination area in a manner that would representative for the entire model. The fragment of the structure was selected by performing a number of numerical simulations using the MSC.Marc/ Mentat software, based on the Finite Elements Methods (FEM). The process of selecting the right fragment was divided into stages, with the area including delamination reduced in the subsequent steps, and with its parameters compared against those achieved in the full demonstrator model. The following parameters were compared: critical loads determined in the linear buckling analysis $\left(P_{k l}\right)$, distribution of the energy release rate along the front delamination line and strains in the delamination area. A detailed description of the work performed in order to select the final fragment of the structure is presented in report [3].

The tests presented in the article aimed to verify, experimentally, the numerical model of the FS selected. Strength testing was performed in the laboratory of the Institute of Aviation's Materials and Structures Research Center. In order to perform field measurements of the deformations, the Digital Image Correlation (DIC) method has been used during the experimental tests. The tests were performed by KSM Vision and by the Institute of Micromechanics and Photonics of the Warsaw University of Technology. Digital Image Correlation (DIC) - is an optical, three-dimensional and contactless methods enabling the measurement of strains and displacements of any point in the space measured, for each time in which the measurement has been taken [4]. The reliability of this particular method has been verified on numerous occasions, by comparing the results with experimental data, e.g. $[5,6,7,8]$. The method finds an ever increasing use in various areas of science and technology, and has already been described in detail in a number of research papers. For instance, DIC has been used to analyze local deformations in areas of geometric discontinuities and material heterogeneity [9]. Determination of mechanical properties of bone tissue may serve as another example here [10]. Furthermore, the Digital Image Correlation system has been used to measure the development of composite material cracking $[11,12]$. Tests relying on the DIC method have also been conducted to assess the impact of stress loads on the distribution of deformations and on the change in strength properties of steel samples [13].

\section{TEST PIECE}

\subsection{Experimental samples}

The workpiece constitutes a fragment of the structure from the central part of the TEBUK project demonstrator. The fragment selected is marked in Fig. 1 with a broken, black line. 


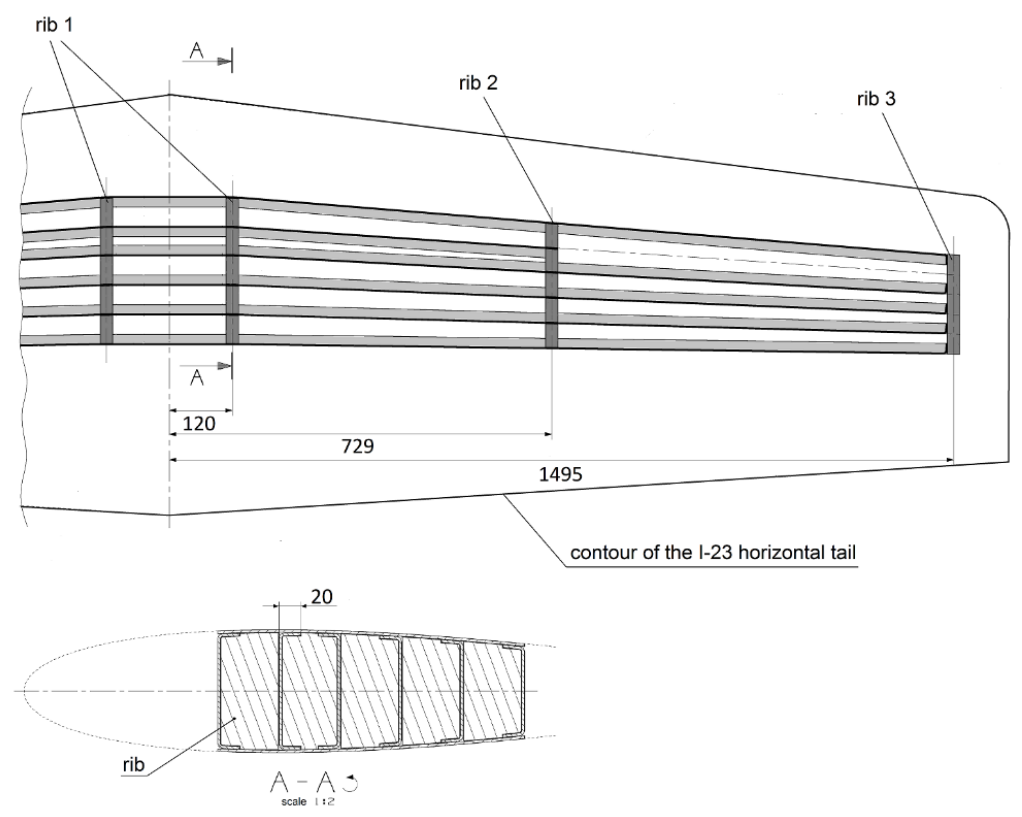

Fig. 1. TEBUK project demonstrator with the tested structure fragment marked [2]

The skins were made of the unidirectional MTM46/HTS40(12K)-150-35\%RW prepreg with the following layer configuration: [0/90/0/90/0/0/45/-45/-45/45]. where the $0^{\circ}$ direction coincides with the span of the stabilizer. The walls of FS have been made of MTM46/CF3004A-42\%RW $\left(199 \mathrm{~g} \mathrm{~m}^{2}\right.$, $2 \times 2$ twill HTA-3K) prepreg carbon fabric with the following layer configuration: $[0 / 45 / 45 / 45]_{\mathrm{s}}$. Additionally, two teflon inserts with the diameter of $40 \mathrm{~mm}$ and thickness of $<0.013 \mathrm{~mm}$ each have been molded in the FS during the manufacture process. The inserts were placed directly in the center of FS, between the third and the fourth composite layer. The center of the delamination area is located $78 \mathrm{~mm}$ away from the surface of the first outer wall (with the entire demonstrator model taken into consideration - Fig. 2).

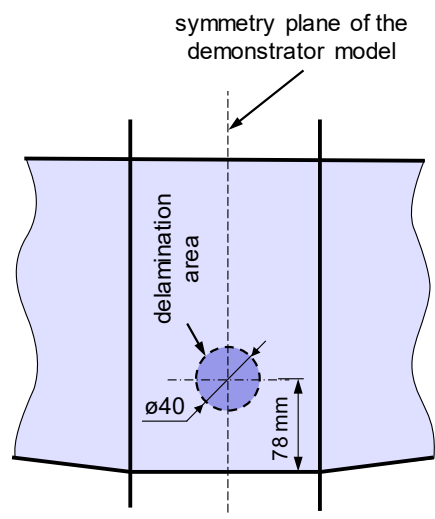

Fig. 2. Location of the delamination area relative to the entire demonstrator model [own elaboration, 2016] 
The composite elements of FS (walls and skins) were made with the use of the "Out of Autoclave" (OoA) method, and cured in accordance with the scheme presented in Figure 3.

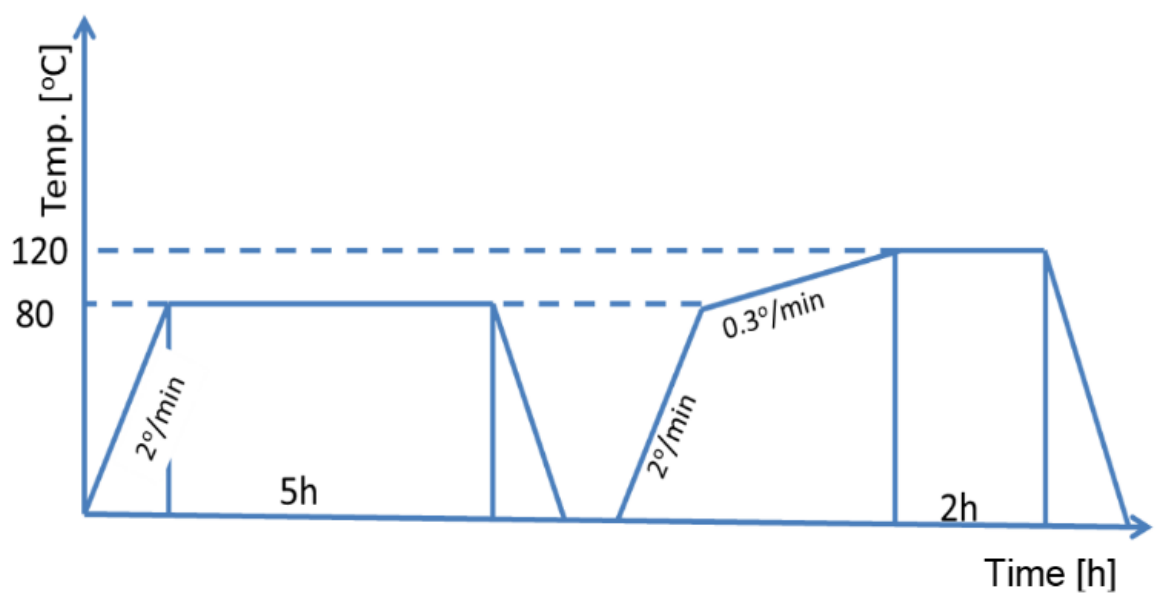

Fig. 3. Curing cycle diagram [own elaboration, 2015]

The walls and the skin have been connected with the use of Hysol 9394 adhesive. The finished FS is presented in Figure 4.

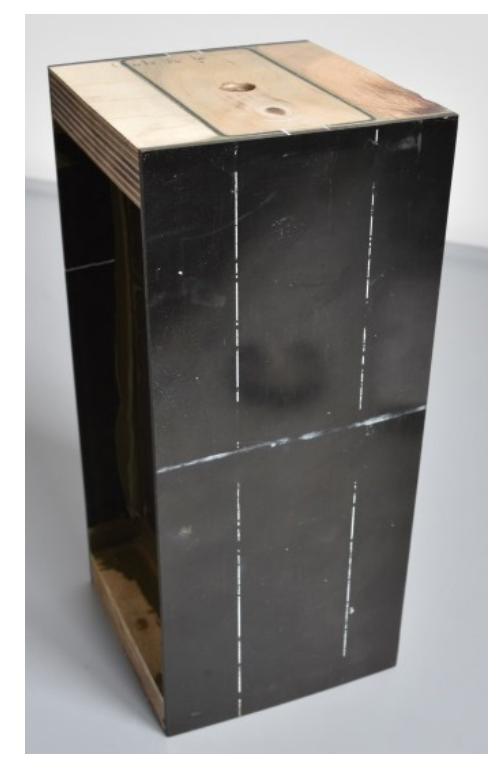

Fig. 4. The finished fragment of the demonstrator's structure [own elaboration, 2016]

In order to smooth out any rough areas and to ensure that the loads are distributed evenly during the compression phase, the samples were positioned in U-profiles prepared in advanced, and flooded with epoxy resin mixed with sand, as shown in Figure 5. The outer bottom section of the steel 160UNP 
U-profile has been milled to ensure that it is perfectly flat. Inside, the U-profile was ground with the use of an angle grinder, to ensure that all corrosion has been removed. Then, two layers of $0 / 90200 \mathrm{~g} \mathrm{~m}^{2}$ glass fabric, positioned on the bottom of the U-profile, were saturated with L335 resin with 335 hardener, mixed in the proportion of 100:38. The FS, with proper load applied, was positioned on the composite layers inside the U-profile. The FS was flooded, inside the U-profile, with a mixture of resin and sand, up to the height of approx. $1.5 \mathrm{~cm}$. The upper part of the FS has been treated accordingly.

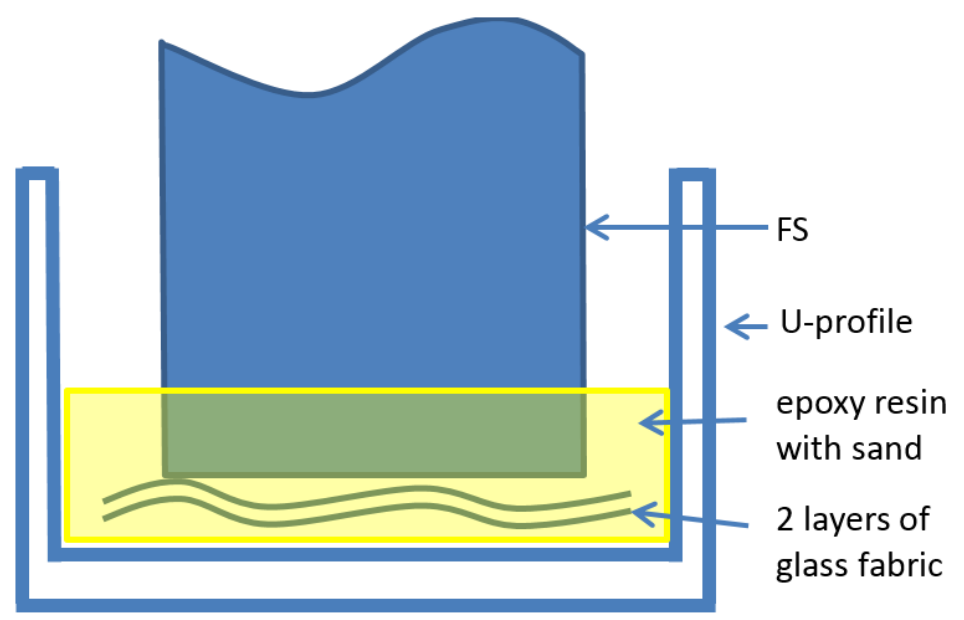

Fig. 5. Simplified diagram showing the FS positioned inside the U-profile and flooded with resin [own elaboration, 2015]

\subsection{Development of the numerical model}

Numerical analysis of the model based fully on Solid-type elements exceeded the calculation capacity of the workstation available. Hence, it was decided that the model should be simplified, and modeled based on Shell-type elements (Fig. 6). The grid of Shell-type elements is additionally approximately 10 time less dense than that of Solid-type elements. The numerical model was built based on Shell-type elements labeled, according to the MARC nomenclature, as 75 and 138, and on Solid-type elements labeled as 185 . As it was the case with the experimental model, delamination area measuring $40 \mathrm{~mm}$ and positioned in the lower skin, between the 3rd and the 4th layer of the laminate (from the surface of the mold) has been introduced to the numerical model. The delamination area and its vicinity (measuring 100x100 mm) has been modeled with the use of a regular grid of finite Solid-type elements measuring $1 \mathrm{x} 1 \mathrm{~mm}$, while the remaining fragments of the structure have been modeled with the use of Shell-type elements (Fig. 6). 

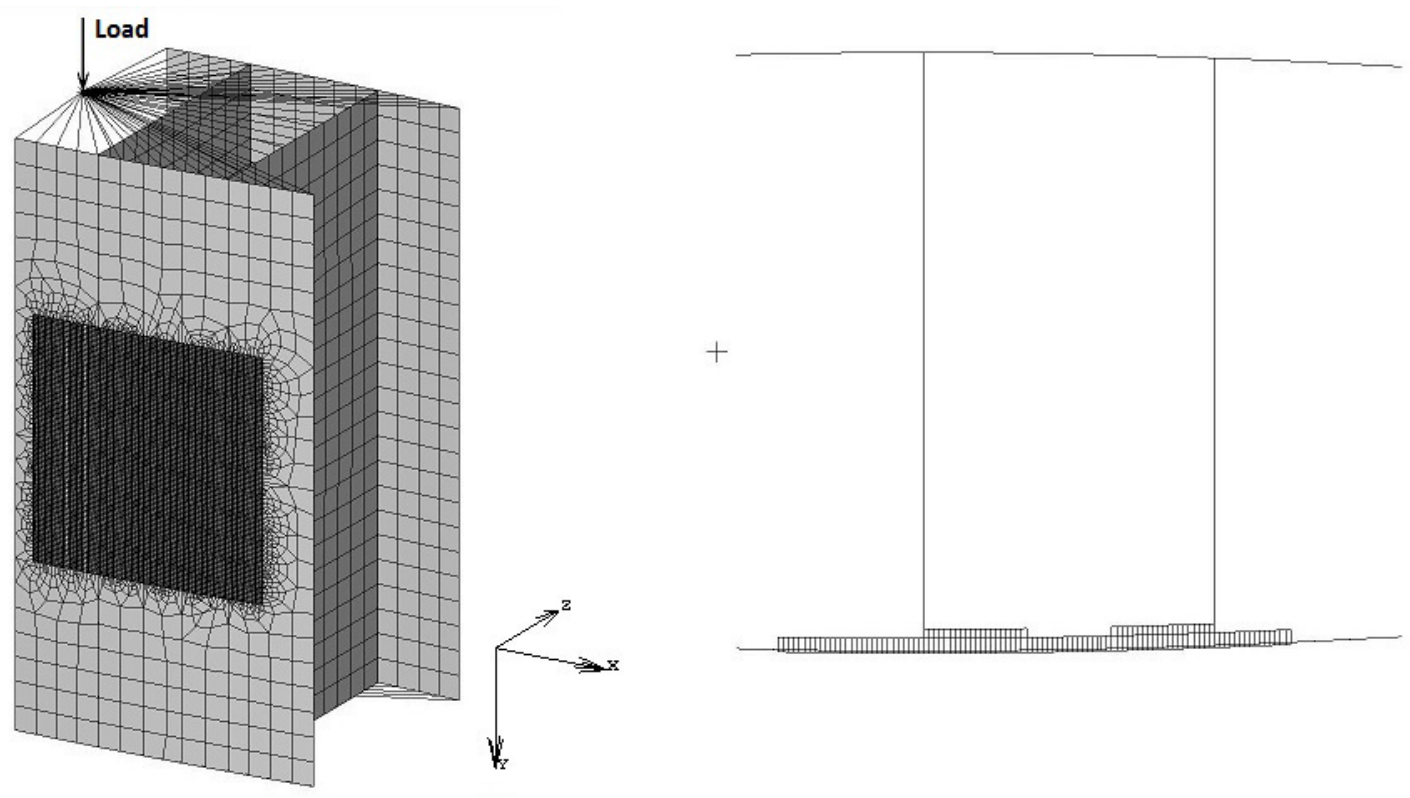

Fig. 6. View of the numerical model and its symmetrical cross section [own elaboration, 2015]

Areas of solid- and shell-type elements were joined in such a way that shell-type elements overlapped the solid-type elements. In order to avoid excessive stiffness of the structure at the joints, they were only 1 element wide $(1 \mathrm{~mm})$. In order to make sure that no excessive stiffness of the structure has been experienced locally at the joints, verification has been performed based on the numerical results obtained from a model built solely with the use of shell-type element. The grid has been designed to be denser throughout the delamination area (compared to the remaining portions of the model), to make sure that the behavior of the delamination experienced while subjecting the model to increasing loads, may be rendered as closely as possible. The use of a homogeneous grid, in turn, was intended to minimize the impact that the shape of the grid may have on the development of delamination $[14,15]$. Preliminary delamination has been introduced into the numerical model by removing the node connections of solid-type elements in the area intended for delamination. The development of delamination has been analyzed with the use of the Critical Crack Closure Technique (VCCT). In this method, calculations of the energy release rate $(G)$, describing the composite material's resistance to inter-layer cracking, are performed based on the forces and node displacement of the FEM model [16]. In the analysis described herein, one of the simplest criteria determining a rupture of the connection between nodes constituting the delamination line has been applied, having the form of (1):

$$
\frac{G_{I}}{G_{I c}}+\frac{G_{I I}}{G_{I I C}}+\frac{G_{I I I}}{G_{I I I C}}=1
$$

where $G_{P}, G_{I I}$ and $G_{I I I}$ are energy release rate for the first, second and third cracking mode, respectively, while $G_{I C}, G_{I I C}$ and $G_{I I C}$ are critical energy release rate. The parameters used in the calculation are as follows $G_{I C}=300 \mathrm{~N} / \mathrm{m}, G_{I I C}$ and $G_{I I C}=900 \mathrm{~N} / \mathrm{m}[15]$. 


\section{BOUNDARY CONDITIONS AND MODEL LOADS}

The compressive load was attached to the model along the $Y$ axis, at two single nodes (Fig. 6), from which it was transferred, via rigid RBE2 elements, to nodes of walls and skins edges. The nodes to which the load was applied are located at intersection of the lines of resultant forces affecting the entire stabilizer [1], and the symmetry line of the stabilizer's cross section. At the points to which the load was attached, the following degrees of freedom were identified: $u_{x}=0 ; u_{z}=0 ; r_{y} t_{y}=0$ and rot $t_{z}=0$, where $u_{X}$ is the displacement towards the $X$ axis; $u_{Z}$ is the displacement towards the $Z$ axis; rot $t_{Y}$ are the rotation along the $Y$ axis and $\operatorname{rot}_{Z}$ are the rotation along the $Z$ axis.

\section{MATERIAL PERFORMANCE OF THE TESTED OBJECT}

Elastic properties of the material used in the numerical model were based on the characteristics of the MTM46/HTS40(12K)-150gsm-35\%RW unidirectional carbon-epoxy prepreg (skin) and MTM46/CF0300-199gsm (walls), as specified by their manufacturer - Advanced Composites Group (table 1):

Tab. 1. Elastic properties of materials used in the numerical model

\begin{tabular}{|l|c|c|}
\hline Rigidity factor & MTM46/HTS40(12K)-150gsm-35\%RW & MTM46/CF0300-199gsm \\
\hline$E_{11}, \mathrm{MPa}$ & 128290 & 59860 \\
\hline$E_{11}, \mathrm{MPa}$ & 8760 & 59860 \\
\hline$E_{11}, \mathrm{MPa}$ & 8760 & 8760 \\
\hline$v_{12}$ & 0.288 & 0.200 \\
\hline$v_{13}$ & 0.288 & 0.320 \\
\hline$v_{23}$ & 0.320 & 0.320 \\
\hline$G_{12}, \mathrm{MPa}$ & 4270 & 4170 \\
\hline$G_{13}, \mathrm{MPa}$ & 4270 & 3000 \\
\hline$G_{23}, \mathrm{MPa}$ & 3000 & 3000 \\
\hline
\end{tabular}

\section{DESCRIPTION OF EXPERIMENTAL TESTS}

The DIC method requires that the surface analyzed be prepared properly. The surface of the sample has been cleaned and painted white. Then, with the use a spray-gun, small black droplets were sprayed over the white surface. The pattern produced was highly contrasting, and random (Fig. 7). The surface conditioned in the manner described above was used during the test to measure full-field displacement and strains. 


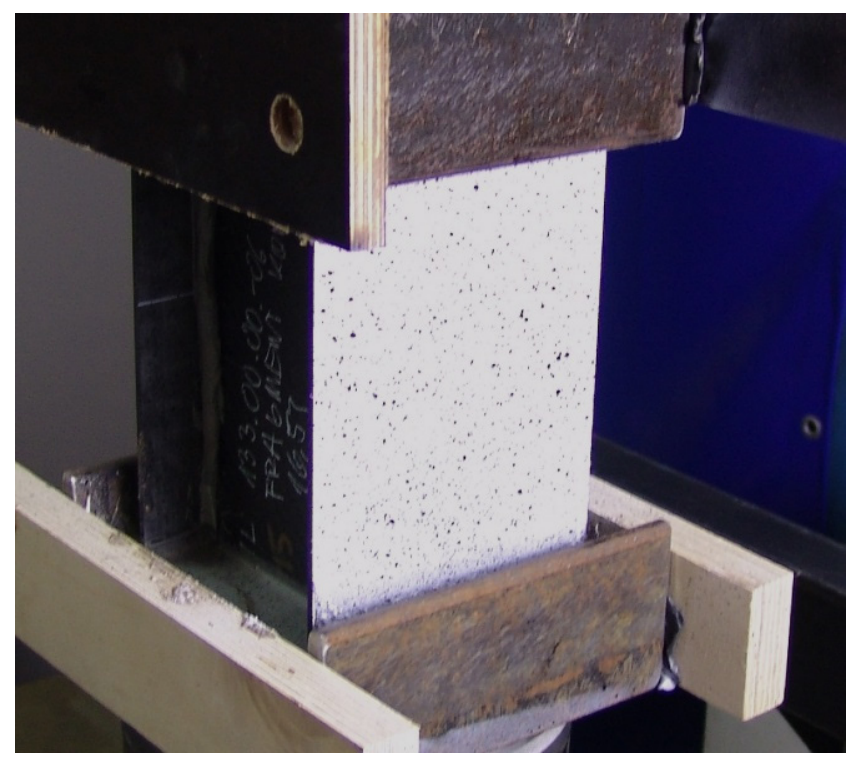

Fig. 7. Sample with test surface covered with white paint and randomly applied pigment [own elaboration, 2015]

The painted sample was positioned in the strength testing rig (Fig. 8) generating the maximum load of $50 \mathrm{t}$, and was subjected to static compression. Unfortunately, the test rig is not equipped with an adapter enabling the forces applied and the shifting observed during the test to be recorded digitally. The shift values have been obtained with the use of the DIC method. The load attached to the sample was increasing at the rate of $0.05 \mathrm{t} / \mathrm{s}$, until destruction of the workpiece (Fig. 9).

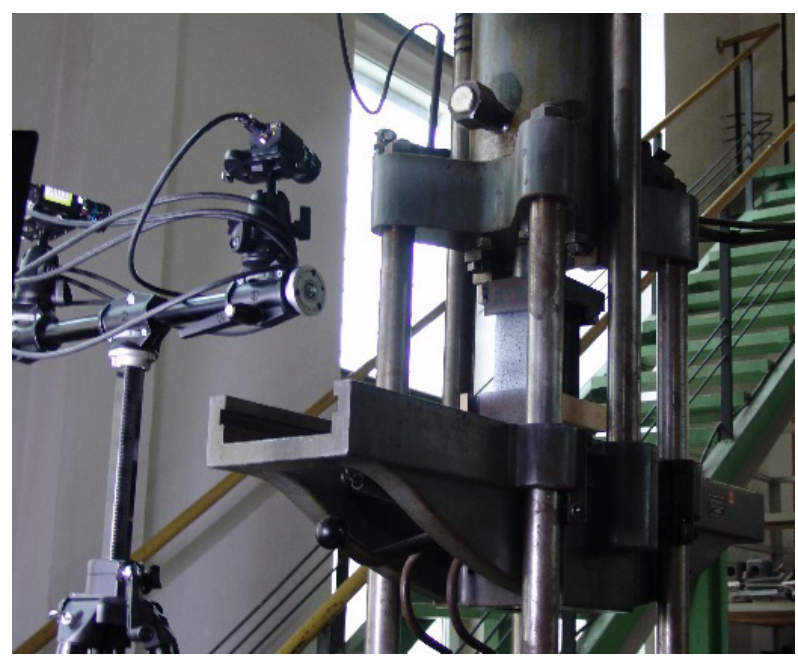

Fig. 8. Measurement stand [own elaboration, 2015] 


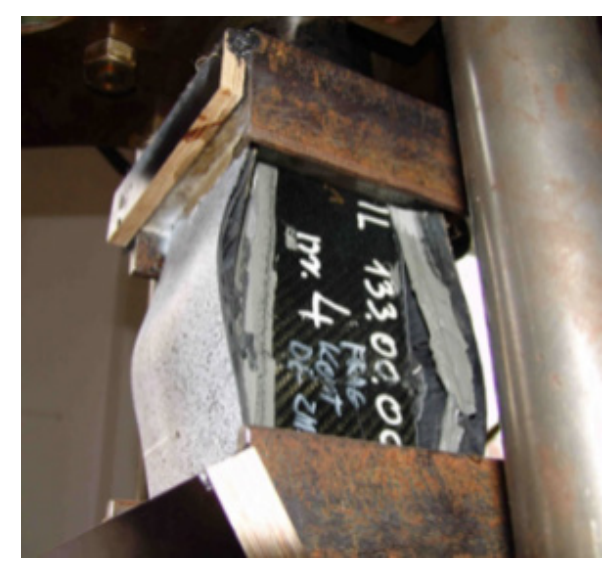

Fig. 9. FS after the static compression test [own elaboration, 2015]

\section{COMPARISON OF EXPERIMENTAL AND NUMERICAL RESULTS}

The DIC method makes it possible to register deformations and shifts along the entire surface measured. This article focuses on the most characteristic points of the delamination area. Therefore, comparison of experimental and numerical results has been limited to selected points only. Figure 10 presents the FS points tested. These included: center of delamination (point 2), and points above the delamination edge, along the lines that were perpendicular (points 1 and 3) and parallel (points 4 and 5) to the direction of compression.

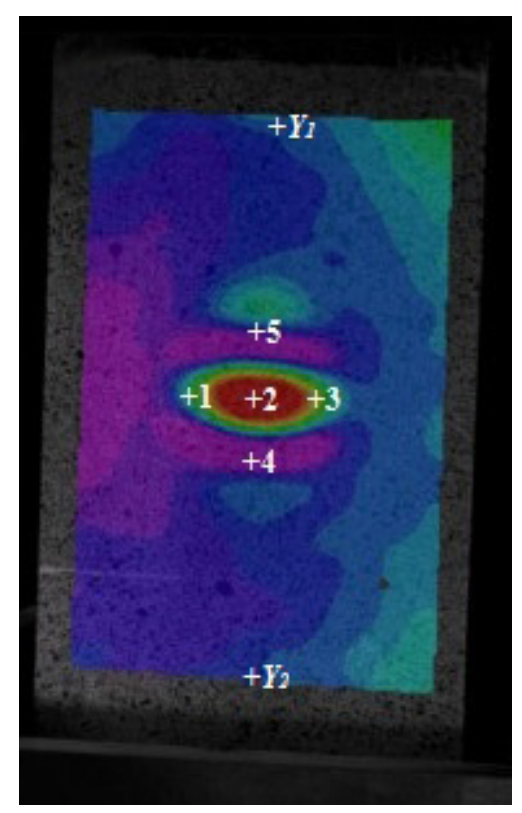

Fig. 10. Location of points at which deformation measurements were compared with numerical results [own elaboration, 2016] 
As the testing rig is not capable of recording the force applied to the workpiece, all values compared are presented as a function of compressive displacement. The compressive displacement of the workpiece has been determined based on the DIC method, and constitutes the distance increase of two outermost points on the upper and lower part of the measurement area, located along the axis of the compressive load ( $Y_{1}$ i $Y_{2}$ - Fig. 10). The distance between $Y_{1}$ and $Y_{2}$ points equals $140 \mathrm{~mm}$. It is worth highlighting that the displacement measured directly on the sample made it possible to eliminate the impact of elasticity of all elements of the measurement system positioned between the piston of the test rig and the sample tested. The compressive displacement of the numerical model corresponds to the mutual displacement between the nodes representing points $Y_{1}$ and $Y_{2}$ in the experimental model (Fig. 10). The distribution of strains and displacements determined numerically (FEM) and experimentally (DIC), immediately prior to rupture, is presented in Figure 11.
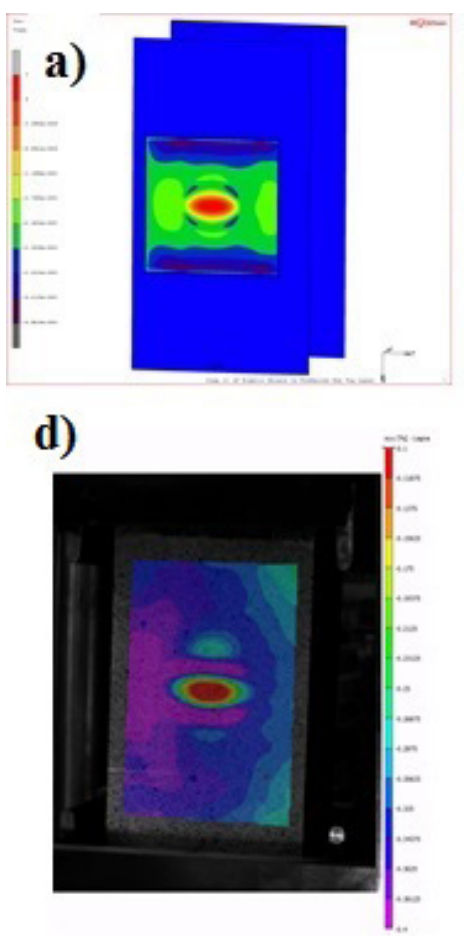

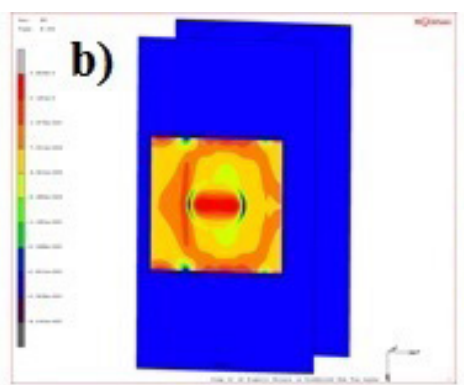

e)

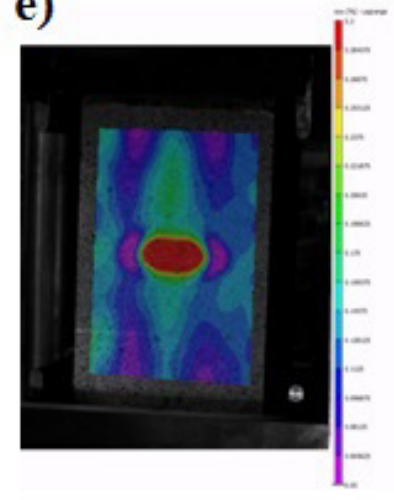

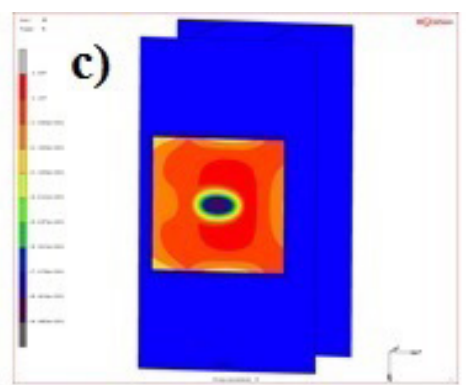

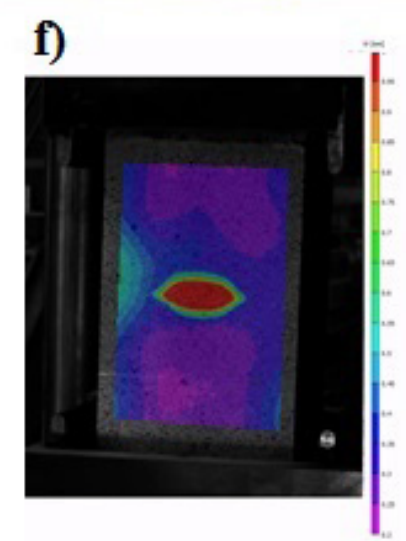

Fig. 11. Comparison of numerical ( $a, b$ and $c)$ and experimental results (d, e and $f$ ),

based on the map of strains and displacements: a) and d) map of strains in the compression direction;

b) and e) map of laterally strains to compression direction; c) and f) map of perpendicular displacement to the surface tested [own elaboration, 2016]

Figures $12 \div 16$ show the variation of strain as a function of the compressive displacement. The following diagrams have been presented for each of the measurement points considered:

a. starin in the compressive direction $\varepsilon_{y}$ as a function of compressive displacement $Y$,

b. strain in the lateral direction to compressive direction $\varepsilon_{\chi x}$ as a function of compressive displacement $Y$. 


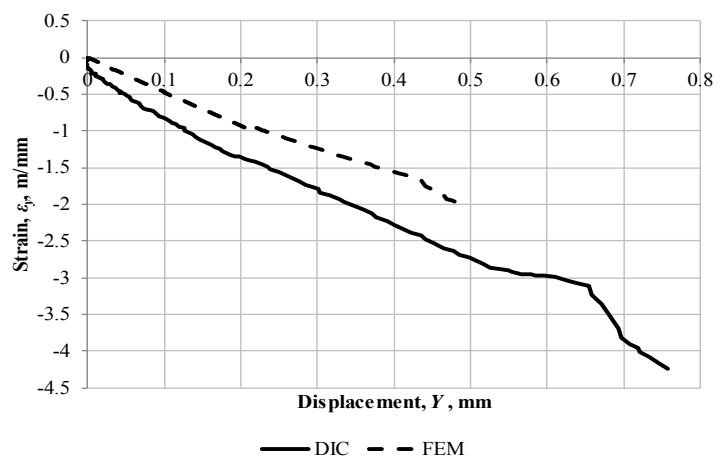

a)

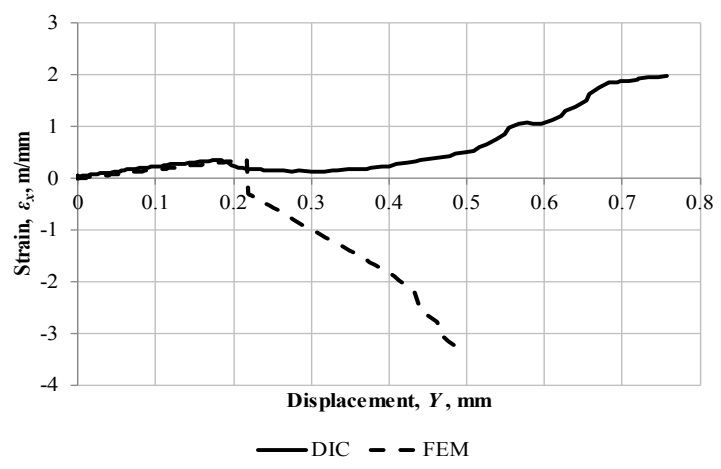

b)

Fig. 12. Strain versus displacement for point 1: a - strain in compressive direction $\varepsilon$;

b strain in lateral direction to compressive direction $\varepsilon_{x}$ [own elaboration, 2016]

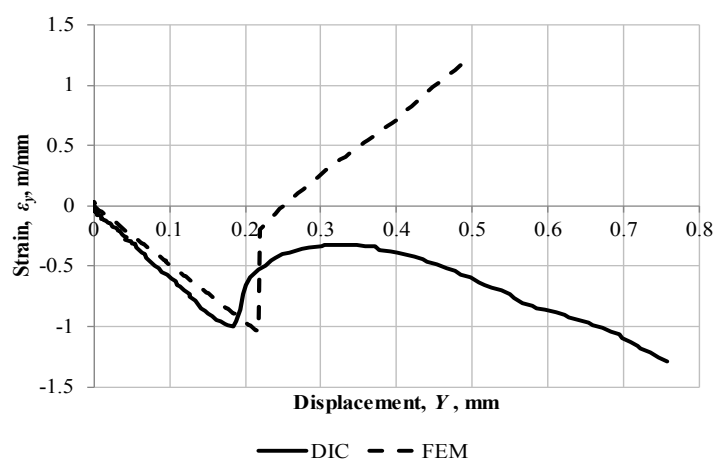

a)

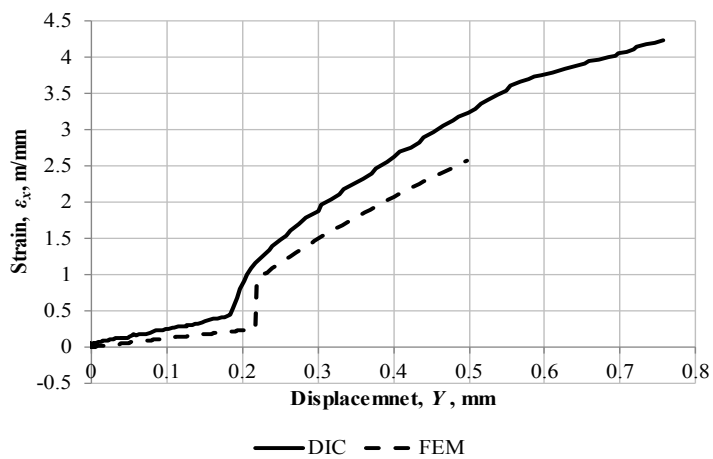

b)

Fig. 13. Strain versus displacement for point 2: a - strain in compressive direction $\varepsilon_{y}$;

b strain in lateral direction to compressive direction $\varepsilon_{x}$ [own elaboration, 2016]

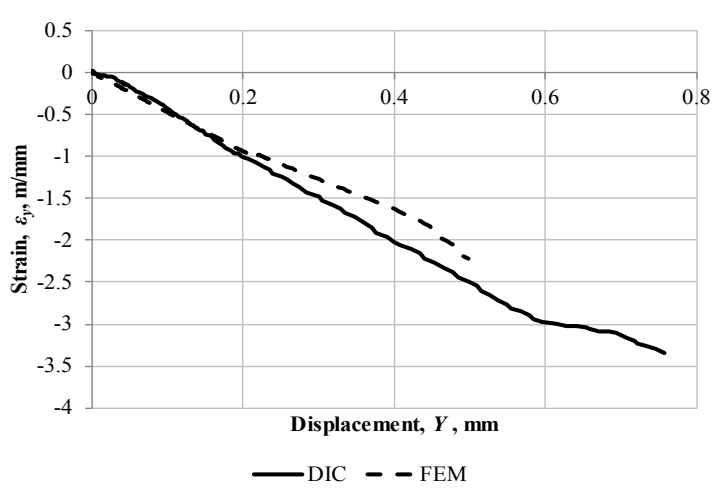

a)

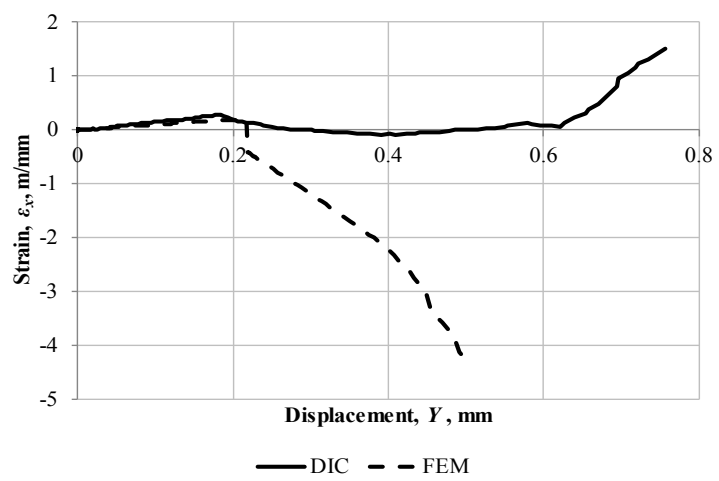

b)

Fig. 14. Strain versus displacement for point 3: a - strain in compressive direction $\varepsilon_{y}$;

b strain in lateral direction to compressive direction $\varepsilon_{x}$ [own elaboration, 2016] 


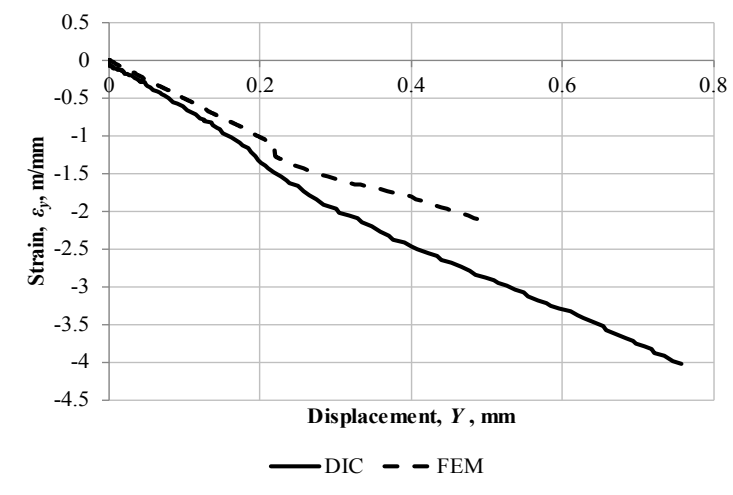

a)

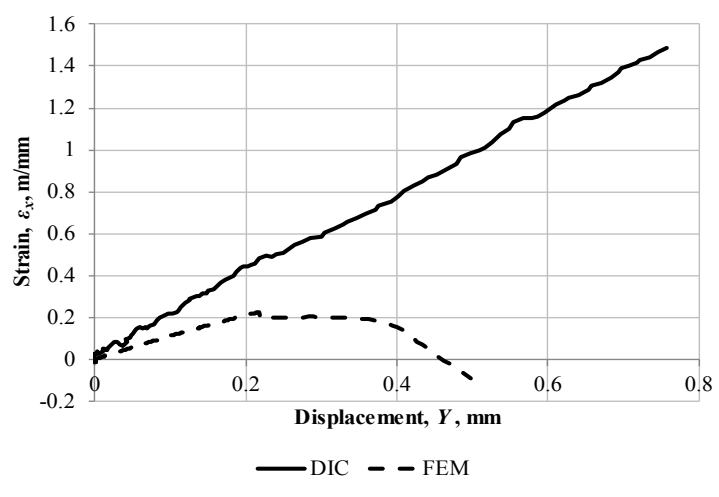

b)

Fig. 15. Strain versus displacement for point 4: a - strain in compressive direction $\varepsilon_{y}$;

b strain in lateral direction to compressive direction $\varepsilon_{x}$ [own elaboration, 2016]

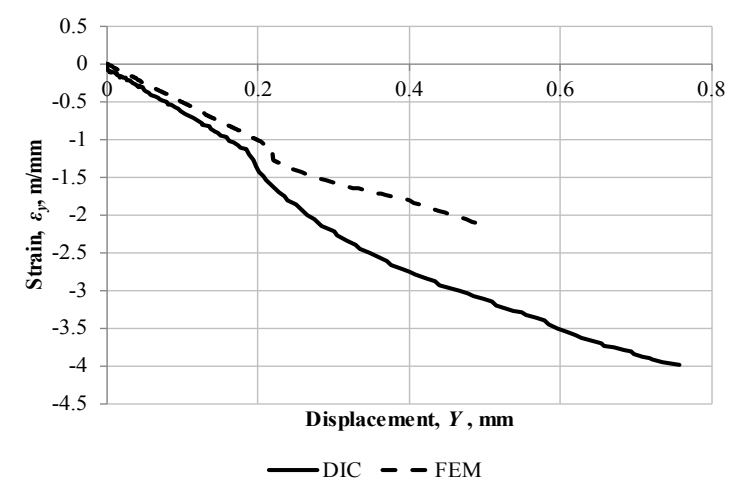

a)

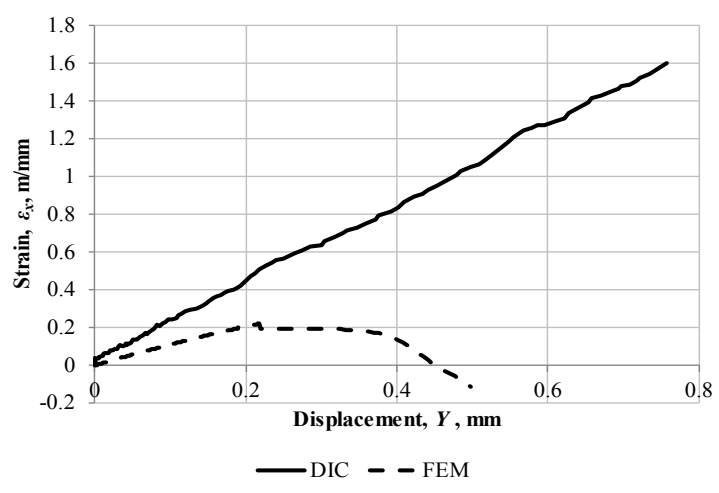

b)

Fig. 16. Strain versus displacement for point 5: a - strain in compressive direction $\varepsilon_{y}$;

b strain in lateral direction to compressive direction $\varepsilon_{x}$ [own elaboration, 2016]

\section{CONCLUSIONS}

The results of the tests allow to the following conclusions to be drawn:

1. Investigation of the strain, as a function of compressive displacement, for the point situated in the very center of the delamination (point 2, Fig. 13) shows that the buckling moment of the skin layer above the delamination area, determined experimentally, is slightly earlier than the one determined numerically ( $Y=0.22 \mathrm{~mm}$ for FEM and $Y=0.18 \mathrm{~mm}$ for DIC). The discrepancy may stem from the fact that the measuring system was characterized by specific rigidity resulting from a finite precision of manufacture of SF, from the quality of the composite components (walls and skins), and from the quality of the bond between the walls and the skins. The numerical mode, in turn, reflected an ideal case.

2. Based on the strain in the compression direction $\varepsilon_{y}$ registered in the points above the edge of preliminary delamination on the line that was parallel to the load (point 4 and 5 - Fig. 15 and Fig. 16, respectively), the propagation of delamination along the direction of the load was assessed. Strain 
registered at that point decrease during the compression tests, meaning that the delamination does not increase along the direction of the compression, which is also confirmed by experiments performed with the use of flat samples [15,17].

3. Diagrams depicting strains in the direction that is lateral compared to the compressive load $\varepsilon_{x^{\prime}}$ at points 1, 3, 4 and 5 (Fig. 12b, 14b, 15b and 16b), just after the loss of stability and buckling of the skin layers above the delamination area, indicate a discrepancy between experimental and numerical results. Strains determined numerically are of the decreasing variety, which means that the sample is compressed at the points in question. Strains determined experimentally, in turn, continue to increase at points 4 and 5, and decrease at points 1 and 3 , just to start growing again.

4. All differences referred to above could be attributed to two factors: despite the use of resin intended to reduce uneven pressure values, the load attached while compressing the edges of the fragment of the structure could be uneven, e.g. due to a failure to ensure that the upper and lower edges of FS remain perfectly parallel to each other; the walls of the experimental sample could start detaching during the compression phase (a conclusion based on the final destruction of the sample (Fig. 9)), which may be the other factor that explains the differences obtained. In the numerical model, in turn, the connection between the walls and the skins was modeled based on the shared-node principle, which representing a perfect connection case.

5. In order to diagnose the discrepancies in the results obtained in more detail, it is recommended that further research be conducted.

6. Strain results $\varepsilon_{x}$ measured experimentally at points 1 and 3 (Fig. $12 \mathrm{~b}$ and $14 \mathrm{~b}$ ), located on a line that is perpendicular to load direction, over the preliminary delamination edge, indicate that the delamination was propagate laterally compared to the direction of the load. This is proven by the increase in the strain after the compressive displacement value of $0.6 \mathrm{~mm}$ was exceeded.

7. After reaching the compressive displacement value of $0.5 \mathrm{~mm}$, at which the delamination is expected to begin to propagate, the numerical analysis was interrupted due to the difficulties connected with the non-linear character of the calculations. Therefore, the comparison of numerical and experimental results concerned with propagation of delamination has not been performed.

\section{BIBLIOGRAPHY}

[1] Osmęda, A., 2012, „Strength and construction analysis of aerospace test structure - Internal report (Analiza wytrzymałościowo-konstrukcyjna demonstratora, Raport wewnętrzny)," 05/BU/2012/ TEBUK, Institute of Aviation, Warsaw.

[2] Osmęda, A., 2016, "Result comparison of numerical analysis and structural tests of aerospace test structure (Porównanie wyników analiz numerycznych i prób wytrzymałościowych demonstratora struktury lotniczej)," Transactions of the Institute of Aviation, Warsaw, No. 244(3). pp. 123-134.

[3] Bajurko, P., 2015, "Modeling subcomponent of demonstrator of tebuk project - Internal report (Modelowanie subkomponentu demonstratora TEBUK, Raport wewnętrzny)," 68/LK/2015/TEBUK, Institute of Aviation, Warsaw.

[4] Chu, T. C., Ranson, W. F., and Sutton, M. A., 1985, "Applications of digital-image-correlation techniques to experimental mechanics," ResearchGate, No. 25(3), pp. 232-244.

[5] Lagattu, F., Brillaud, J., and Lafarie-Frenot, M.-C., 2004, "High strain gradient measurements by using digital image correlation technique," Materials Characterization, No. 53(1), pp. 17-28. 
[6] Tomblin, J., and Seneviratne, W., 2011, Determining the Fatigue Life of Composite Aircraft Structures Using Life and Load-Enhancement Factors, Air Traffic Organization NextGen \& Operations Planning Office of Research and Technology Development Washington, DC 20591.

[7] Gower, M. R. L., and Shaw, R. M., 2010, "Towards a Planar Cruciform Specimen for Biaxial Characterisation of Polymer Matrix Composites," Applied Mechanics and Materials, No. 24-25, pp. 115-120.

[8] Leone, F. A., Bakuckas, J. G., Shyprykevich, P., and Davies, C., 2008, Structural Testing and Analysis of Honeycomb Sandwich Composite Fuselage Panels, Air Traffic Organization Operations Planning Office of Aviation Research and Development Washington, DC 20591.

[9] Szala, J., and Boroński, D., 2007, "Local strain analysis in the zones of geometrical discontinuities and material inhomogeneities (Analiza odkształceń lokalnych w obszarach nieciąłości geometrycznych i niejednorodności materiałowych)," Acta Mechanica et Automatica, Vol. 1, No. 1, pp. 103-124.

[10] Kokot, G., 2013, „Determination of mechanical properties of bone tissues using digital image correlation, nanoindentation and numerical simulations (Wyznaczanie własności mechanicznych tkanek kostnych z zastosowaniem cyfrowej korelacji obrazu, nanoindentancji oraz symulacji numerycznych)," Silesian University of Technology.

[11] Battams, G. P., Dulieu-Barton, J. M., and Boyd, S. W., 2010, "Evaluation of Edge Cracks in Cross-Ply Laminates Using Image Correlation and Thermoelastic Stress Analysis," Applied Mechanics and Materials, No. 24-25, pp. 91-96.

[12] Gonzalez, J., and Knauss, W. G., 1998, "Strain inhomogeneity and discontinuous crack growth in a particulate composite," Journal of the Mechanics and Physics of Solids, No. 46(10), pp. 1981-1995.

[13] Moćko, W., 2015, "The use of digital correlation of the image to evaluate the impact of initial fatigue loads on the strain distribution and changes in the strength properties of $\mathrm{dp} 500$ steel (Zastosowanie cyfrowej korelacji obrazu do oceny wpływu wstępnych obciążeń zmęczeniowych na rozkład odkształcenia i zmiany właściwości wytrzymałościowych stali DP500)," Motor Transport, Z. 2, Motor Transport Institute, Warsaw, pp. 89-108.

[14] Wilk, J., 2015, "Assessing the hazard of delamination propagation in composites using numerical analysis," Composites Theory and Practice, R. 15, No. 1, pp. 34-38.

[15] Bajurko, P., Wilk, J., Szeląg, D., and Czarnocki, P., 2014, "Numerical modeling of delamination growth in composite plates," Shell Structures, Theory and Applications, CRS Press, Gdańsk, pp. 373-376.

[16] Krueger, R., 2004, "Virtual crack closure technique: History, approach, and applications," Appl. Mech. Rev, No. 57(2), pp. 109-143.

[17] Bajurko, P., and Czarnocki, P., 2014, "Numerical and experimental investigations of embedded delamination growth caused by compressive loading," Journal of Theoretical and Applied Mechanics, No. 52(2), pp. 301-312.

The tests described in the paper have been performed under the TEBUK project entitled "Development of technologies used to examine damage resistance of aeronautical grade, composite, load-bearing structures", POIG.01.01.02-14-017. The project has been financed by the European Regional Development Fund, under the Innovative Economy - National Cohesion Strategy program. 


\section{EKSPERYMENTALNA WERYFIKACJA OBLICZEŃ NUMERYCZNYCH Z ZASTOSOWANIEM CYFROWEJ KORELACJI OBRAZU}

\section{Streszczenie}

Artykuł dotyczy prac badawczych realizowanych w ramach projektu TEBUK, którego głównym celem było opracowanie wzorcowej metodyki oceny wpływu uszkodzeń na wytrzymałość konstrukcji wykonanych z preimpregnatów węglowo epoksydowych. Obiektem prezentowanych badań był fragment struktury (FS) demonstratora projektu TEBUK wykonany z kompozytu węglowo-epoksydowego ze sztucznie wprowadzoną delaminacja kołową o średnicy $40 \mathrm{~mm}$. Wykonano numerycznie i eksperymentalnie badania FS w warunkach quasi-statycznego obciążenia ściskającego, w trakcie których analizowano wyboczenie pokrycia w obszarze delaminacji oraz jej propagację. Obliczenia numeryczne przeprowadzono w komercyjnym pakiecie obliczeniowym MSC Marc/Mentat bazującym na metodzie elementów skończonych. Wyniki analiz numerycznych porównywano z pomiarami eksperymentalnymi zmierzonymi metodą Cyfrowej Korelacji Obrazu (CKO). Przeprowadzone badania miały za zadanie wstępną weryfikację modelu numerycznego. Uzyskane wyniki wykazały bardzo dobrą zbieżność wyników numerycznych i eksperymentalnych dotyczących obciążeń krytycznych, w których następuje utrata stateczności (wyboczenie) warstw odseparowanych delaminacją. Natomiast brak zbieżności obliczeń w modelu numerycznym po przekroczeniu obciążeń krytycznych nie pozwolił jednoznacznie porównać wyników dotyczących propagacji delaminacji.

Słowa kluczowe: cyfrowa korelacja obrazu, MES, delaminacja, wyboczenie, laminat węglowo-epoksydowy. 